\title{
Variations in pituitary-gonadal suppression during intranasal buserelin and intramuscular depot-triptorelin therapy for central precocious puberty
}

\author{
C Heinrichs', M Craen ${ }^{2}$, M Vanderschueren-Lodeweyckx ${ }^{3}, \mathrm{P} \mathrm{Malvaux}^{4}$, L Fawe ${ }^{5}$ and JP Bourguignon ${ }^{5}$ \\ Departments of Pediatrics, Universities of Brussels ${ }^{3}$, Ghent $^{2}$, Leuven $^{3}$, Louvain $^{4}$ and Liège ${ }^{5}$, Belgium, in collaboration with the Belgian Study \\ Group for Pediatric Endocrinology
}

\begin{abstract}
Heinrichs C, Craen M, Vanderschueren-Lodeweyckx M, Malvaux P, Fawe L, Bourguignon JP. Variations in pituitary-gonadal suppression during intranasal buserelin and intramuscular depottriptorelin therapy for central precocious puberty. Acta Pædiatr 1994;83:627-33. Stockholm. ISSN 0803-5253

This study evaluated pubertal development, growth and pituitary-gonadal suppression in 21 patients with central precocious puberty treated with buserelin intranasally and switched after a mean of $2.1 \mathrm{yr}$ to depot-triptorelin given im for 1 year. Arrest or regression of puberty was observed in 12 patients while progression of puberty during therapy was seen in 9 patients ( 6 on buserelin, 2 on triptorelin and 1 on both therapies). The increment in serum LH and FSH concentrations after sc injection of shortacting triptorelin was greater on buserelin than on triptorelin therapy, particularly in patients with evidence of progression of puberty. Height velocity during therapy showed a reduction which paralleled the decelerating phase of the normal pubertal growth spurt. The rate of bone maturation during therapy was inversely related to pretreatment bone age. Predicted final height showed marked individual variations which were inversely related to predicted adult height before therapy. These data indicate that differences in the nature and route of administration of Gn-RH agonist therapy for central precocious puberty can be of importance for inhibition of pituitary gonadotropin secretion and development of secondary sex characteristics. Height velocity and bone maturation are age-related and the change in predicted adult height depends on pretreatment level. $\square$ Buserelin, GnRH agonist, growth, maturation, precocious puberty, triptorelin
\end{abstract}

JP Bourguignon, Department of Pediatrics, CHR de la Citadelle, Bd du 12e de Ligne, 1 B-4000 Liège, Belgium

Central precocious puberty results from premature reactivation of the hypothalamo-pituitary-gonadal axis. The treatment of this condition aims to arrest or cause regression of the development of secondary sex characteristics and to prevent premature fusion of bone epiphyses resulting in small final height.

For this purpose, gonadotropin releasing hormone $(\mathrm{Gn}-\mathrm{RH})$ agonist therapy was proposed some 10 years ago $(1,2)$. Since then, different schedules have been used, depending on the nature, dosage and route of administration of the agonist. Initially, multiple daily intranasal administration of buserelin or nafarelin was used (3-9). Single daily sc injections of triptorelin, buserelin, leuprolide or deslorelin were proposed also (10-17). More recently, monthly im injections of longacting forms of triptorelin or leuprolide have been used as more reliable preparations (18-23).

In Belgium, therapy was started using intranasal administration of buserelin. As reported previously, some patients showed progression of puberty despite a documented suppression of Gn-RH-induced gonadotropin secretion (6). Therefore, it was decided to switch to depot-triptorelin therapy and to compare, retrospec- tively, the data obtained during buserelin therapy with those obtained prospectively during one year of depottriptorelin therapy. In addition, the gonadotropin secretory response to the administration of a short-acting Gn-RH agonist was studied during treatment with either agonist.

\section{Patients and methods}

Central precocious puberty was diagnosed in 21 patients (16 girls and 5 boys) based on the following criteria: onset of breast development before 8 years of chronological age in girls or testicular volume $\geqslant 4 \mathrm{ml}$ (Prader's orchidometer) before 9 years in boys, increased rate of growth and bone maturation, and pubertal pattern of gonadotropin response to $\mathrm{Gn}-\mathrm{RH} 25 \mu \mathrm{g} / \mathrm{m}^{2}$ iv. The etiology was idiopathic in 1 boy and 12 girls. In 2 boys and 1 girl, precocious puberty occurred following radiotherapy and/or surgical treatment of a brain tumor. An hamartoma accounted for precocious puberty in 2 girls. One girl had congenital hydrocephalus and 1 boy congenital toxoplasmosis. In 1 boy, central 
precocious puberty was secondary to peripheral precocious puberty caused by a Leydig cell tumor. One girl and 1 boy had associated hypopituitarism and they were on appropriate replacement therapy, including GH. However, since GH therapy could bias the growth data, these 2 patients were not included in the auxological part of the study.

The mean chronological age of the patients at initiation of buserelin therapy was 5.3 years (range $0.7-8.8$ years) and mean bone age was 8.4 years (range 1.6-12.9 years). Buserelin was administered intranasally (1.2-2.4 $\mathrm{mg}$ /day, divided into 3-4 daily doses) for a mean (SEM) period of 2.1 ( 0.3 ) years (range $0.3-5.3$ years). The mean daily dose of buserelin was 49 (SD 15) $\mu \mathrm{g} / \mathrm{kg}$ (range 26$77 \mu \mathrm{g} / \mathrm{kg}$ ). All patients were switched to depot-triptorelin therapy at a dose of $3.75 \mathrm{mg}$ im every four weeks and they were followed for one year. The mean four-week dose of depot-triptorelin was $0.13(0.04) \mathrm{mg} / \mathrm{kg}$ (range $0.08-0.24 \mathrm{mg} / \mathrm{kg}$ ). At the time of the switch to triptorelin, mean (SEM) chronological age was $7.4(0.5)$ years and mean bone age was $10.9(0.5)$ years. Informed consent was obtained from all families. The study was approved by the local Ethics Committee.

At three-month intervals, height was measured using a Harpenden stadiometer and pubertal development was scored according to Tanner (24), using the stages of genital development in boys and breast development in girls. An X-ray of the left hand and wrist was obtained at yearly intervals during burserelin therapy, as well as at the switch to depot-triptorelin therapy and one year later. The films were read by two independent pediatric radiologists. Because they provided estimates with a sensitivity of one-tenth of a year, the readings according to Tanner et al. (25), based on radius, ulna and short bones, were used to assess changes in bone age during therapy. The readings according to Greulich \& Pyle (26) were used also since predicted adult height (PAH) was calculated according to Bayley \& Pinneau (27). In 4 patients, pretreatment PAH could not be calculated since the patients were too young.

In each patient, a gonadotropin stimulation test using short-acting triptorelin $(0.1 \mathrm{mg} \mathrm{sc})$ was performed on two occasions. The initial test was performed $12 \mathrm{~h}$ after the last administration of buserelin. The second test was done 28 days after the third depot-triptorelin injection. Blood was collected before and at 30 -min intervals between 180 and $360 \mathrm{~min}$ after triptorelin injection. Luteinizing hormone (LH) and follicle stimulating hormone (FSH) secretory responses to triptorelin were calculated as the difference between pretreatment level and the highest level observed after injection of the agonist. LH and FSH were measured in a single laboratory using a highly sensitive enzyme immunoassay. The reagents were supplied by Medgenix Belgium. The assay was performed in duplicate using $0.05 \mathrm{ml}$ of serum and a specific immunoradiometric assay of LH and FSH was run comparatively. The detection limit of the assay was $0.15 \mathrm{mIU} / \mathrm{ml}$ for $\mathrm{FSH}$ and $0.10 \mathrm{mIU} / \mathrm{ml}$ for LH. The within-assay and between-assay coeffcients of variation were $5.3 \%$ and $8.3 \%$ respectively for LH and $4.2 \%$ and $8.9 \%$ respectively, for FSH. The cross reactivity of the alpha-subunit in the assays was $<0.1 \%$. The data obtained using the enzyme immunoassay (ELISA) and the immunoradiometric assay (IRMA) were very close, as shown by the following equations of linear correlation where $\mathrm{x}=$ IRMA data and $\mathrm{y}=$ ELISA data (LH: $\mathrm{y}=0.99 \mathrm{x}+0.98, \quad r=0.95 ; \quad \mathrm{FSH}: \mathrm{y}=$ $0.94 \mathrm{x}+0.78, r=0.95$ ). In boys, serum testosterone concentrations were measured using standard radioimmunoassays in each center involved in the study. In girls, serum estradiol levels were measured in each center. However, the data obtained were excluded from further analysis because of a major difference in assay sensitivity among the centers involved in the study.

The data obtained at different times during the study using buserelin and depot-triptorelin therapy were compared using the paired Student's $t$-test. The correlations were examined by calculation of linear regression and analysis of variance. Differences were considered to be significant at a $5 \%$ critical level.

\section{Results}

\section{Pubertal development and treatment adequacy}

As shown in Table 1, arrest or regression of genital development was observed during therapy with either agonist in 5 boys. All had plasma testosterone levels in the normal prepuberal range $(<0.05 \mathrm{ng} / \mathrm{ml})$ during therapy. Among the 16 girls, 9 showed progression of puberty during therapy since, in 1 girl, puberty progressed during treatment with either agonist. In these 9 girls, the mean daily dose of the agonist was not different from that given to the other patients. Although some patients reported occasional delay in the administration of buserelin, no failure of compliance could be detected.

\section{Gonadotropin response to triptorelin}

Figure 1 shows the maximal increments in LH and FSH secretion in response to sc administration of shortacting triptorelin. During buserelin therapy, the mean responses of LH and FSH to triptorelin were significantly greater than during depot-triptorelin treatment $(p<0.05)$. During buserelin therapy, the response of LH to triptorelin was greater in patients showing progression of puberty than in those showing arrest of puberty (mean 7.4 (SD 3.9) versus $1.8(0.9) \mathrm{mIU} / \mathrm{ml} ; p<0.001$ ). To a lesser extent, a similar observation was made for FSH $(p<0.05)$. During depot-triptorelin therapy, LH and FSH responses $>4 \mathrm{mIU} / \mathrm{ml}$ were observed in 2 girls. One was clinically well suppressed during buserelin therapy and showed a low LH response at that time. During depot-triptorelin therapy, her mother noticed breast budding during the week before each administra- 
Table 1. Effects of two GnRH agonists on Tanner stages of pubertal development in 16 girls and 5 boys with central precocious puberty.

\begin{tabular}{|c|c|c|c|}
\hline & $\begin{array}{l}\text { Before GnRH } \\
\text { therapy }\end{array}$ & $\begin{array}{l}\text { At switch from } \\
\text { buserelin to depot-triptorelin }\end{array}$ & $\begin{array}{l}\text { After } 1 \mathrm{yr} \text { on } \\
\text { depot-triptorelin }\end{array}$ \\
\hline \multicolumn{4}{|c|}{ Stages of genital development in boys } \\
\hline G1 & - & 1 & 1 \\
\hline G2 & 2 & 1 & 1 \\
\hline G3 & 3 & 3 & 3 \\
\hline G4 & - & - & \\
\hline \multicolumn{4}{|c|}{ Overall change during therapy } \\
\hline Arrest/regression & & 5 & 5 \\
\hline progression & & 0 & 0 \\
\hline \multicolumn{4}{|c|}{ Stages of breast development in girls } \\
\hline M1 & - & 3 & 2 \\
\hline M2 & 5 & 4 & 6 \\
\hline M3 & 11 & 7 & 7 \\
\hline M4 & - - & 2 & 1 \\
\hline \multicolumn{4}{|c|}{ Overall change during therapy } \\
\hline Arrest/regression & & 9 & 13 \\
\hline Progression & & 7 & 3 \\
\hline
\end{tabular}

tion of the agonist with subsequent disappearance after injection. The other patient was not well suppressed during buserelin treatment and showed a marked LH response to the initial test. She showed vaginal bleeding after the third administration of depot-triptorelin. She
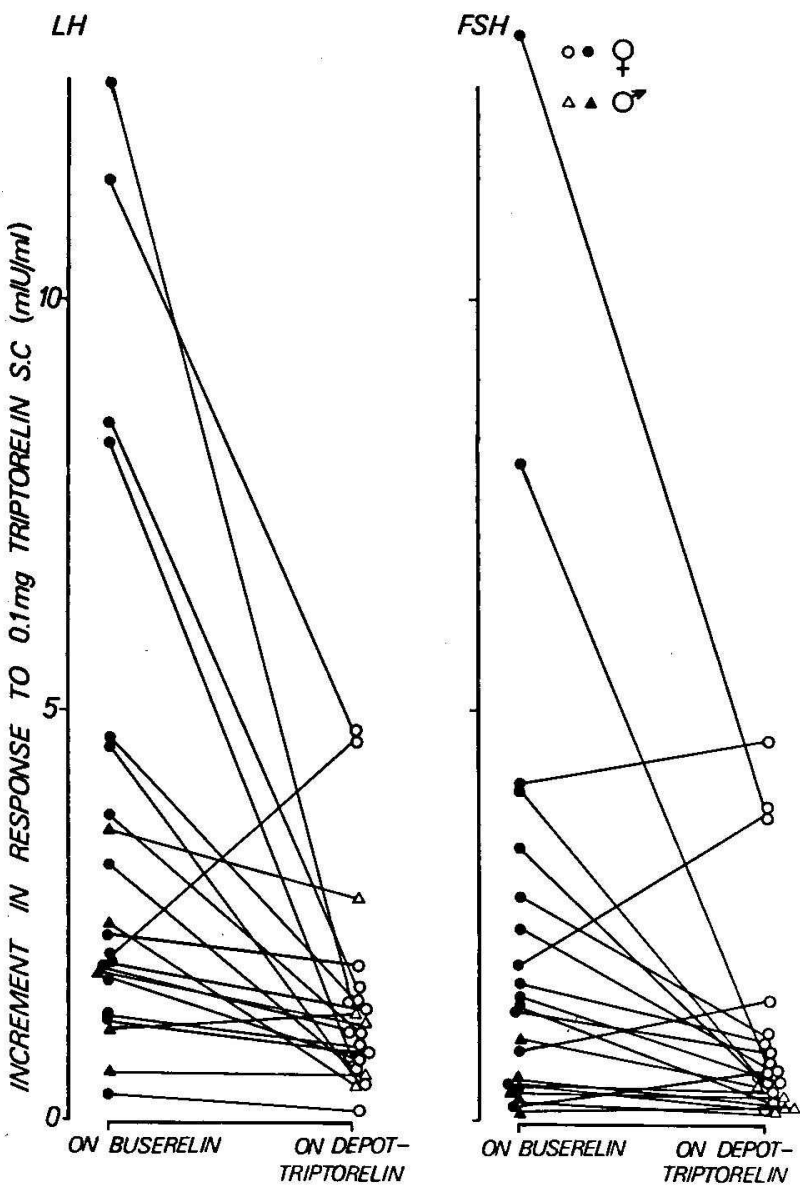

was clinically well suppressed during the subsequent nine-month period.

\section{Growth and bone maturation}

As shown in Fig. 2, height velocity (HV) showed a steady decline during treatment with both buserelin and depot-triptorelin. In most patients, the decline in HV paralleled the decelerating phase of the normal pubertal growth spurt. The mean reduction in HV between the last year of buserelin therapy and the first year on depottriptorelin was $2.8(1.5) \mathrm{cm} /$ year. This reduction is similar to that seen at the 50th centile of the decelerating phase of the growth spurt in normal girls $(2.2-3.0 \mathrm{~cm} /$ year).

In Fig. 3, the individual values for the change in bone age (BA) in relation to chronological $(\mathrm{CA})(\triangle \mathrm{BA} / \Delta \mathrm{CA})$ during the last year on buserelin therapy are plotted in relation to BA attained one year before the switch. Also the values of $\triangle \mathrm{BA} / \triangle \mathrm{CA}$ after the switch to depottriptorelin are plotted in relation to BA at the switch. During buserelin therapy, no correlation was observed whereas during depot-triptorelin therapy, a negative correlation was found between $\triangle \mathrm{BA} / \Delta \mathrm{CA}$ and $\mathrm{BA}$ (Fig. $3)$. At a similar $B A$, lower values of $\triangle B A / \triangle C A$ were observed during depot-triptorelin than during buserelin therapy.

Before Gn-RH agonist therapy, the mean (SEM) SDS of PAH was $-1.2(0.3) \mathrm{SD}$. This value was significantly lower $(p<0.05)$ than the sex-corrected midparental

Fig. 1. Individual values of maximal increment in serum concentrations of LH (left panel) and FSH (right panel) after SC administration of $0.1 \mathrm{mg}$ triptorelin in 21 patients with central precocious puberty. The initial test was performed during buserelin therapy, immediately before switch to depot-triptorelin. The second test was performed after 3 months of treatment using depot-triptorelin. The lines connect values obtained at the two tests in each individual patient. 


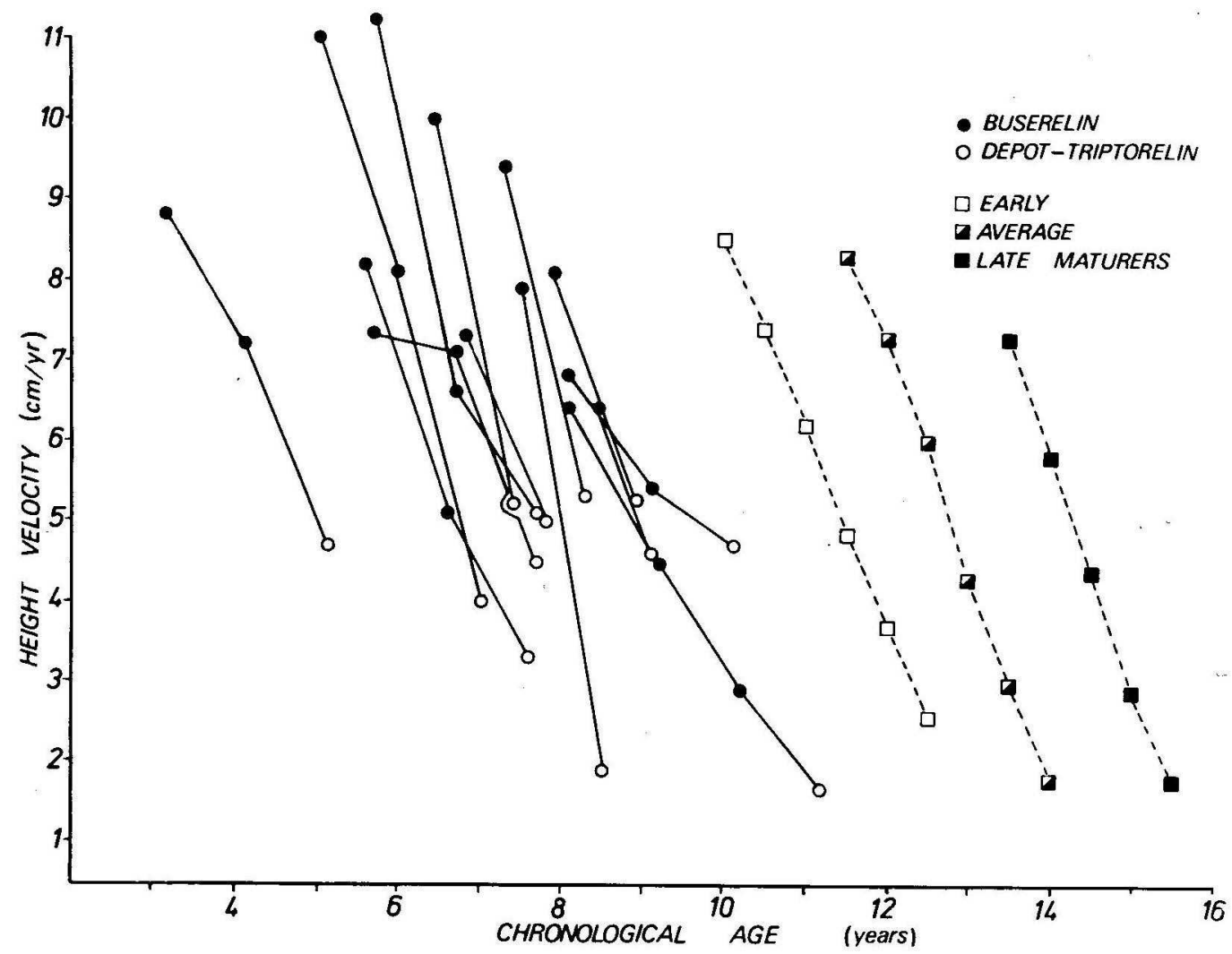

Fig. 2. In 13 girls central precocious puberty, height velocity is plotted in relation to chronological age during buserelin therapy and, subsequently, during depot-triptorelin therapy. For comparison purposes, the 50th centile of height velocity for chronological age during the decelerating phase of the normal pubertal growth spurt is shown in early, average and late maturers (Tanner and Davies, 43).

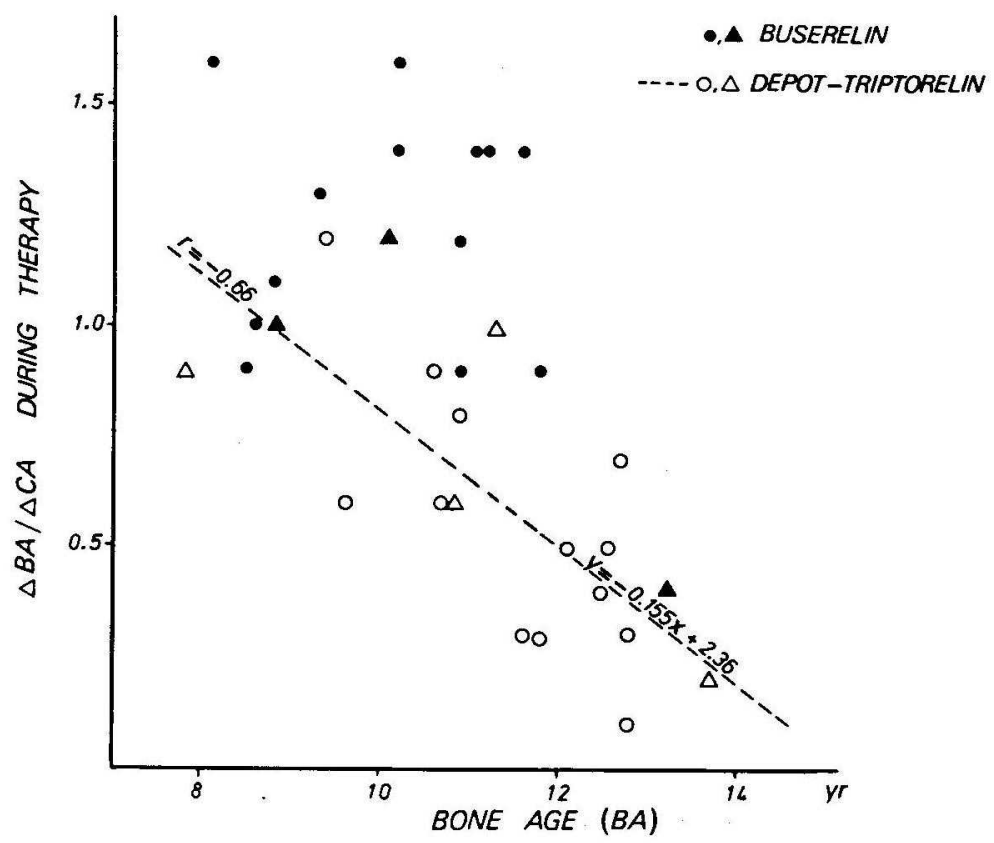

Fig. 3. Bone age increment $(\triangle \mathrm{BA})$ per 1 year of chronological age $(\mathrm{CA})$ during buserelin or depot-triptorelin therapy in patients with central precocious puberty. Data are represented as a function of bone age observed at the beginning of each study year of $\mathrm{GnRH}$ agonist therapy. Triangles denote data obtained in boys and circles in girls. 


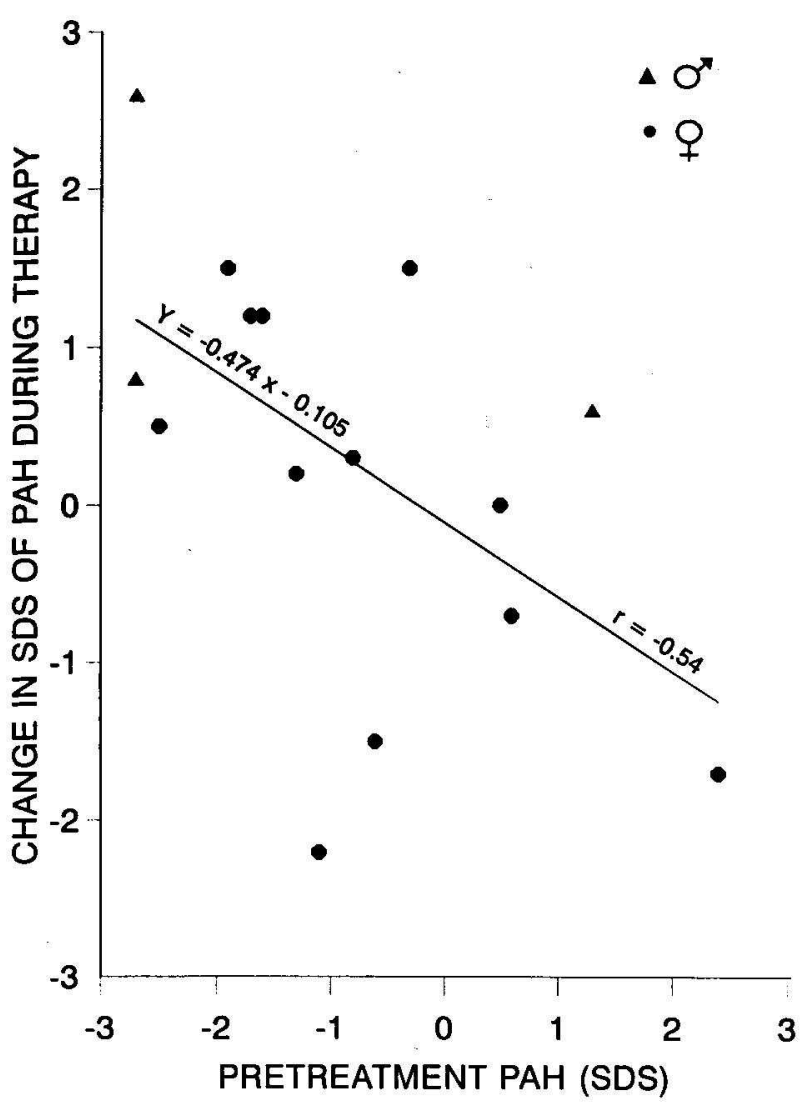

Fig. 4. Linear correlation between predicted adult height (PAH) before GnRH agonist therapy and change in predicted adult height after GnRH agonist therapy for a mean of 3.1 years in patients with central precocious puberty. When PAH could not be calculated before therapy on account of age, the first predicted height calculated during therapy was used as pretreatment data.

height $(+0.1(0.2) \mathrm{SD})$. No significant change in mean PAH was observed during buserelin therapy, one year before the switch to depot-triptorelin $(-1.0(0.3) \mathrm{SD})$ or at the switch $(-1.0(0.4) \mathrm{SD})$. Neither was the mean PAH different after one year of depot-triptorelin therapy $(-0.9(0.4) \mathrm{SD})$, with important individual variations. No significant correlation was found between the change in PAH during therapy and CA or BA at onset of therapy or pretreatment height SDS for BA. The change in PAH during Gn-RH agonist therapy was negatively correlated $(r=-0.54 ; p<0.05)$ to pretreatment PAH (Fig. 4).

\section{Discussion}

In this study, we have evaluated the effects of two $\mathrm{Gn}$ RH agonists used sequentially in patients with central precocious puberty. Due to evidence of incomplete suppression of pubertal development in a number of patients after several months of buserelin treatment, it was decided to switch to depot-triptorelin therapy and to evaluate the clinical and biochemical changes. Incomplete pituitary-gonadal suppression was reported using intranasal preparations of Gn-RH agonists $(5,6,9,28)$, as well as daily $\mathrm{sc}$ injections of buserelin or leuprolide acetate $(11,17,29,30)$. These observations could be explained by differences in biopotency or plasma concentrations of the agonists, and possible failure of compliance $(31,32)$. Using depot preparations of different Gn-RH agonists, arrest or regression of puberty was reported uniformly $(18-20,23)$. In our series of 21 patients, 3 were not adequately suppressed during depot-triptorelin therapy. This could be related to the undetectable plasma levels of the agonist reported in some patients four weeks after administration (33). Such an observation was also made by Brauner et al. (20) who proposed administration of depot-triptorelin every 25 days.

While some authors suggested a possible role of the dose of Gn- $\mathrm{RH}$ agonist on the growth rate and progression of puberty (34), others found only dose-related differences in suppression of gonadotropin secretion without any effect on growth and puberty (35). In this study, no significant correlation was found between the dosage of Gn-RH agonist and the effects on the development of secondary sex characteristics. Of particular interest is the fact that, in this study, all the boys treated for central precocious puberty were well suppressed during buserelin therapy whereas almost half of the girls treated under similar conditions were not well suppressed. This finding could be related to a sex difference in activity of the central "gonadostat" which seems to switch more easily to a pubertal pattern of function in girls than in boys. Indeed, the incidence of central precocious puberty is higher in girls than in boys, in contrast to delayed puberty. According to such a concept, inhibitory factors such as Gn-RH agonists could be less effective on the central mechanism of puberty in girls than in boys. In our small series of 7 girls not well suppressed during buserelin therapy, precocious puberty was found to be idiopathic in 4 and organic in 3 , suggesting that the etiology was unlikely to play a major role in the clinical response to therapy.

How to assess the degree of pituitary-gonadal suppression during $\mathrm{Gn}-\mathrm{RH}$ agonist therapy is still an unsolved issue. We found previously that the gonadotropin response to a standard Gn-RH test was of little value since patients treated with buserelin uniformly showed an abolished response to Gn-RH, including those with evidence of progression of puberty (6). This is consistent with the recent report of Cook et al. (34). In children with precocious puberty incompletely suppressed by Gn-RH agonist therapy, these authors found that the response of $\mathrm{LH}$ to the $\mathrm{Gn}-\mathrm{RH}$ test was inhibited whereas overnight LH secretion was not. Since the response of the gonadotropins to the $\mathrm{Gn}-\mathrm{RH}$ test appeared not to be useful, different authors attempted to study gonadotropin secretion in response to a Gn-RH agonist. In patients with endometriosis or central precocious puberty, the response of the gonadotropins to acute administration of a Gn-RH agonist was shown to be related to the dose of the agonist administered 
chronically $(35,36)$. In this study, we showed that the response of $\mathrm{LH}$ and FSH to acute administration of the agonist triptorelin was related to the degree of clinical suppression of pubertal development by the Gn-RH agonist therapy. In agreement with Pescovitz et al. (35), the $\mathrm{LH}$ response to the Gn-RH agonist is found to be more discriminant than the FSH response in evaluating the degree of pituitary suppression by treatment with a Gn-RH agonist.

The effects of Gn-RH agonist therapy on growth and bone maturation are confused with the important changes in the rate of growth and bone maturation during normal puberty. In patients with precocious puberty, a mean delay of three years has been observed between the onset of puberty reported by the parents and initiation of Gn-RH agonist therapy (37). Considering such a long delay, particularly in girls who exhibit their growth spurt early during puberty, it is likely that most patients with precocious puberty have reached the decelerating phase of the spurt when Gn-RH agonist therapy is initiated. At that time, despite the increase in plasma levels of sex steroids, the growth rate decreases in normal adolescents and the rate of bone maturation decreases also (38). In GH-treated patients, we have shown that the rate of bone maturation decreased with age during puberty (39). Therefore, the reduction in height velocity and rate of bone maturation during $\mathrm{Gn}$ $\mathrm{RH}$ agonist therapy for precocious puberty can involve a physiological process independent of the treatment and the interpretation of the effects of treatment is difficult. Moreover, comparison between growth effects of buserelin and depot-triptorelin is not possible from our study since there was a one-year difference between the data obtained using the two agonists. In recent reports comparing the effects of buserelin and depottriptorelin in different patients studied under similar age conditions, some authors concluded that PAH was not different (30). Others found that final height shows a 9$\mathrm{cm}$ difference (40). It is possible that the intranasal (40) or sc (32) route of buserelin administration accounts for these different effects. Nevertheless, such a discrepancy further emphasizes the difficulty in comparing the growth effects of the two agonists.

In contrast with the majority of earlier reports (review in 41), we did not find any significant increase in mean PAH during Gn-RH agonist therapy. This can be explained partly by the individual differences in PAH at the initiation of treatment since only those patients with a very short PAH before therapy appeared to increase their adult height prognosis during therapy. This is in agreement with our previous observation after one year of buserelin treatment (5). Equivocal effects on PAH were also reported by others (42). In addition, using daily deslorelin or monthly depot-triptorelin injections, PAH has been shown to decrease between the end of therapy and a second evaluation, two to three years later $(37,41,42)$. Therefore, studies on the final height data are warranted before any conclusion can be drawn on the effects of Gn-RH agonist therapy on ultimate stature. In addition, evaluation of the beneficial effects of such treatment should also consider other issues such as psychological aspects and quality of life for the patients with precocious puberty.

Acknowledgements.-The authors are grateful to the members of the Belgian Study Group for Pediatric Endocrinology for their interest and helpful discussions. They are indebted to Drs C Christophe and $L$ Rausin for reading the bone age films. The authors would like to acknowledge the support from Hoechst AG (Frankfurt, Germany) who graciously provided the patients with buserelin, Ipsen-Biotech (Paris, France) who supplied short-acting and depot-triptorelin and Medgenix Belgium for generous supply of the material for $L H$ and FSH assays. The excellent secretarial assistance of Miss $J$. Laurent is acknowledged. This study was partly supported by a grant from the "Fonds de la Recherche Scientifique Médicale" (3.4574.87).

\section{References}

1. Crowley WF, Comite F, Vale W, Rivier J, Loriaux DL, Cutler G. Therapeutic use of pituitary desensitization with long-acting LHRH agonist: a potential new treatment for idiopathic precocious puberty. J Clin Endocrinol Metab 1981;52:370-2

2. Comite G, Cutler GB, Rivier J, Vale W, Loriaux DL, Crowley WF. Short-term treatment of idiopathic precocious puberty with a long-acting analogue of luteinizing hormone-releasing hormone. N Engl J Med 1981;305:1546-50

3. Luder AS, Holland FJ, Costigan DC, Jenner MR, Wiegosz G, Fazekas ATA. Intranasal and subcutaneous treatment of central precocious puberty in both sexes with a long-acting analog of luteinizing hormone-releasing hormone. J Clin Endocrinol Metab 1984;58:966-72

4. Lin TH, Lepage ME, Henzi M, Kirkland JL. Intranasal nafarelin: an LH-RH analogue treatment of gonadotropin-dependent precocious puberty. J Pediatr 1986;109:954-8

5. Bourguignon JP, Van Vliet G, Vandeweghe M, Malvaux P, Vanderschueren-Lodeweyckx M, Craen, M, Ducaju MVL, Ernould C. Treatment of central precocious puberty with an intranasal analogue of GnRH (buserelin). Eur J Pediatr 1987; 146:550-60

6. Bourguignon JP, Heinrichs C, Van Vliet G, Vandeweghe M, Vanderschueren-Lodeweyckx M, Malvaux P, Ducaju M, Craen R, Lambrechts L, Delire M, Ernould C. Evaluation and significance of the degree of pituitary-gonadal inhibition during intranasal administration of buserelin. Acta Endocrinol (Copenh) 1987;116:519-25

7. Stanhope R, Pringle PJ, Brook CGD. Growth, growth hormone and sex steroid secretion in girls with central precocious puberty treated with a gonadotrophin releasing hormone $(\mathrm{GnRH})$ analogue. Acta Paediatr Scand 1988;77:525-30

8. Rime JL, Zumsteg V, Blumberg A, Hadziselimovic F, Girard J, Zurbrugg RP. Long-term treatment of central precocious puberty with an intranasal LHRH analogue: control of pituitary function by urinary gonadotropins. Eur J Pediatr 1988;147:263-9

9. Kreiter M, Burstein S, Rosenfield RL, Mall GW, Cara JF, Yousefzadeh DK, Cuttler L, Kevitsky LL. Preserving adult height potential in girls with idiopathic true precocious puberty. J Pediatr 1990;117:364-70

10. Kauli R, Pertzelan A, Ben-Zeev Z, Prager Lewin R, Kaufman H, Comaru Schally AM, Schally AV, Laron Z. Treatment of precocious puberty with LHRH analogue in combination with cyproterone actate-further experience. Clin Endocrinol 1984; 20:377-87

11. Brauner R, Thibaud E, Bischop P, Sizonenko PC, Rappaport R. Long-term results of $\mathrm{GnRH}$ analogue (buserelin) treatment in girls with central precocious puberty. Acta Paediatr Scand 1985; 74:945-9

12. Styne DM, Harris DA, Egli CA, Conte FA, Kaplan SL, Rivier J, 
Vale W, Grumbach M. Treatment of true precocious puberty with a potent luteinizing hormone-releasing factor agonist: effect on growth, sexual maturation, pelvic sonography and the hypothalamic-pituitary-gonadal axis. J Clin Endocrinol Metab 1985; 61:142-51

13. Comite F, Cassorla F, Barnes KM, Rudlin CR, Bode HH, Crigler JF, Crawford JD, Crowley WF. Luteinizing hormone releasing hormone analogue therapy for central precocious puberty: long term effect on somatic growth, bone maturation, and predicted height. JAMA 1986;255:2613-6

14. Boepple PA, Mansfield MJ, Wierman ME, Hench KD, Dwyer A, Skerda MC, Loriaux L, Cutler GB, Pescovitz OH. Use of a potent, long acting agonist of gonadotropin-releasing hormone in treatment of precocious puberty. Endocr Rev 1986;7:24-33

15. Drop SLS, Odink RJH, Rouwe C, Otten BJ, Van Maarshalkerweerd MW, Gons M, Bor A, Meradji M, de Jong FH, Slijper FME. The effect of treatment with an LH-RH agonist (buserelin) on gonadal activity, growth and bone maturation in children with central precocious puberty. Eur J Pediatr 1987;146:272-8

16. Sklar CA, Rothenberg S, Blumberg D, Oberfield SE, Levine LS, David R. Suppression of the pituitary-gonadal axis in children with central precocious puberty: effects on growth, growth hormone, insulin-like growth factor-I, and prolactin secretion. J Clin Endocrinol Metab 1991;73:734-8

17. Kappy MS, Stuart T, Perelman A. Efficacy of leuprolide therapy in children with central precocious puberty. Am J Dis Child 1988;142:1061-4

18. Roger M, Chaussain JL, Berlier P, Bost M, Canlorbe P, Colle M, François R, Garandeau P, Lahlou N, Morel Y, Schally AV. Longterm treatment of male and female precocious puberty by periodic administration of a long-acting preparation of D-Trp6-luteinizing hormone-releasing hormone microcapsules. J Clin Endocrinol Metab 1986;62:670-7

19. Hummelink, R, Oostdijk W, Parstsch CJ, Odink RJH, Drop SLS, Sippell WG. Growth, bone maturation and height prediction after three years of therapy with the slow release GnRH agonist decapeptyl-depot in children with central precocious puberty. Horm Metab Res 1992;24:122-6

20. Brauner R, Malandry F, Rappaport R. Predictive factors for the effect of gonadotrophin releasing hormone analogue therapy on the height of girls with idiopathic central precocious puberty. Eur J Pediatr 1992;151:728-30

21. Parker KL, Lee PA. Depot leuprolide acetate for treatment of precocious puberty. J Clin Endocrinol Metab 1989;69:689-91

22. Kappy M, Stuart T, Perelman A, Clemons R. Suppression of gonadotropin secretion by a long-acting gonadotropin-releasing hormone analog (Leuprolide acetate, Lupron depot) in children with precocious puberty. J Clin Endocrinol Metab 1989;69:10879

23. Neely EK, Hintz RL, Parker B, Bachrach LK, Cohen P, Olney R, Wilson DM. Two-year results of treatment with depot leuprolide acetate for central precocious puberty. J Pediatr 1992;121:634-40

24. Tanner JM. Growth at Adolescence, 2nd Edn. Oxford: Blackwell, 1962

25. Tanner JM, Whitehouse RH, Cameron N, Marshall WA, Healy MJR, Goldstein H. Assessment of Skeletal Maturity and Prediction of Adult Height (TW2 Method), 2nd Edn. London, New York: Academic Press, 1983

26. Greulich WW, Pyle SI. Radiographic Atlas of Skeletal Development of the Hand and Wrist, 2nd Edn. Stanford: Stanford University Press, 1959

27. Bayley N, Pinneau SR. Tables predicting adult height from skeletal age: revised for use with Greulich-Pyle hand standards. J Pediatr 1952;40:423-41

28. Stanhope R, Adams J, Broock CGD. The treatment of central precocious puberty using an intranasal LHRH analogue (buserelin). Clin Endocrinol 1985;22:795-806

29. Lee PA, Page JG and the Leuprolide Study Group. Effects of leuprolide in the treatment of central precocious puberty. J Pediatr 1989;114:321-4

30. Partsch CJ, Hümmelink R, Peter M, Sippell WG, Oostdijk W, Odink RJH, Drop SLS. Comparison of complete and incomplete suppression of pituitary-gonadal activity in girls with central precocious puberty: influence on growth and predicted final height. Horm Res 1993;39:111-7

31. Holland GJ, Fishmann L, Costigan DC, Lunal L, Leeder S. Pharmaco-kinetic characteristics of the gonadotropin-releasing hormone analogue D-Ser (TBU)6-EA-10 luteinizing hormonereleasing hormone (buserelin) after subcutaneous and intranasal administration in children with central precocious puberty. J Clin Endocrinol Metab 1986;63:1065-70

32. Sizonenko PC, Reznik Y, Aubert M. Urinary excretion of [DSer(t-Bu)6, Des-Gly10] GnRH ethylamide (buserelin) during therapy of central precocious puberty: a multicentre study. Acta Endocrinol (Copenh) 1990;122:553-8.

33. Lahlou N, Roger M, Canlorbe P, Chaussain JL, Raynaud F, Toublane JE, Schally AV. Plasma levels of D-Trp-6-LHRH (decapeptyl) after intramuscular injection of long-acting microcapsules in children treated for precocious puberty. Pediatr Res 1985;19:635

34. Cook JS, Doty KL, Conn PM, Hansen JR. Assessment of depot leuprolide acetate dose-adequacy for central precocious puberty. J Clin Endocrinol Metab 1992;74:1206-9

35. Pescovitz OH, Barnes KM, Cutler GB. Effects of deslorelin dose in the treatment of central precocious puberty. J Clin Endocrinol Metab 1991;72:60-4

36. Monroe SE, Blumenfeld Z, Andreyko JL, Schriock E, Henzl MR, Jaffe RB. Dose-dependent inhibition of pituitary-ovarian function during administration of a gonadotrophin-releasing hormone agonistic analog (Nafarelin). J Clin Endocrinol Metab 1986;63:1334-41

37. Oerter KE, Manasco P, Barnes KM, Jones J, Hill S, Cutler GB. Adult height in precocious puberty after long-term treatment with deslorelin. J Clin Endocrinol Metab 1991;73:1235 40

38. Buckler JMH. Skeletal age changes in puberty. Arch Dis Child 1984;59:115-9

39. Bourguignon JP, Vandeweghe M, Vanderschueren-Lodeweyckx M, Malvaux P, Wolter R, Du Caju M, Ernould C. Pubertal growth and final height in hypopituitary boys: a minor role of bone age at onset of puberty. J Clin Endocrinol Metab $1986 ; 63: 376-82$

40. Nizzoli G, Chiumello G, Fasolato V, Cisternino M, Antoniazzi F, Bozzola M, Corrias A, De Luca F, De Sanctis C, Rigon F, Severi F, Tato L. Comparison between short-acting and long-acting treatment for central precocious puberty: final data. Horm Res 1992;37(Suppl 4):4

41. Oerter KE, Manasco P, Barnes KM, Jones J, Hill S, Cutler GB. Effects of luteinizing hormone-releasing hormone agonists on final height in luteinizing hormone-releasing hormone-dependent precocious puberty. Acta Paediatr 1993; (Suppl 388):62-8

42. Oostdijk W, Drop SLS, Odink RJH, Hümmelink R, Partsch CJ, Sippell WG. Long-term results with a slow-release gonadotrophin-releasing hormone agonist in central precocious puberty. Acta Paediatr Scand 1991;(Suppl 372):39-45

43. Tanner JM, Davies PSW. Clinical longitudinal standards for height and height velocity for North American children.J Pediatr 1985;107:317-29.

Received April 19, 1993. Accepted Sep. 29, 1993 